\title{
KARAKTERISTIK PELAJAR PENYALAHGUNA NAPZA DAN JENIS NAPZA YANG DIGUNAKAN DI KOTA SURABAYA
}

\author{
Maydiya Restacendi Nur'artavia \\ Departemen Epidemiologi, Fakultas Kesehatan Masyarakat, \\ Universitas Airlangga, Surabaya, Jawa Timur, Indonesia \\ Alamat Korespondensi: \\ Maydiya Restacendi Nur'artavia \\ Email: meidia.na0@gmail.com
}

\begin{abstract}
Drug abusers increases every years, and the student is one of vulnarable group. The students are adolescence group who have emotional instability, and high couriousity about something new because they thinks they already adult. The purpose of this study was to describe drug abuse, and drug type of the student in Surabaya. The research was descriptive which analyzed secondary data in rehabilititation's division BNN Kota Surabaya. The population of this study were the students in Surabaya during 2015. The purposive sampling was used to take sample in this study which consisted of 189 students who recorded by BNN Kota Surabaya. The research was done at Agustus-September 2016 in BNN Kota Surabaya. The results showed that $80.95 \%$ the students were male, in the early teens $(54.5 \%)$. Drug of Choice and drug most often used was double L with the amount of each $97.35 \%$, and $88.89 \%$, and most of the drug being abused was only one type (91.53\%). Most of the students abused drug found in Sawahan and Tegalsari districts. It was concluded that most of the students who use drug were male, in early teen, using double L/Trihexyphenidyl, and coming from Sawahan and Tegalsari. Routine screening on students, and spot inspections need to be done.
\end{abstract}

Keywords: drug abuser, drug type, the student

\begin{abstract}
ABSTRAK
Penyalahgunaan NAPZA setiap tahun semakin meningkat, dan pelajar merupakan salah satu kelompok rawan yang dapat menyalahgunakannya. Pelajar berada pada usia remaja yang memiliki emosi labil, dan merasa dirinya sudah dewasa sehingga ingin mencoba hal-hal yang belum mereka ketahui sebelumnya. Tujuan penelitian adalah mempelajari karakteristik pelajar penyalahguna NAPZA, dan jenis NAPZA yang digunakan di Kota Surabaya. Jenis penelitian adalah deskriptif dengan menganalisis data sekunder yang tersedia pada bagian rehabilitasi BNN Kota Surabaya. Populasi pada penelitian ini adalah pelajar di Kota Surabaya tahun 2015 sedangkan sampel diambil dengan cara purposive sampling yaitu pelajar penyalahguna NAPZA yang dapat dijangkau oleh BNN Kota Surabaya tahun 2015 yang berjumlah 189 pelajar. Penelitian ini dilakukan pada 29 Agustus hingga 27 September 2016. Hasil dari penelitian menunjukkan sebesar $80,95 \%$ pelajar yang menyalahgunakan NAPZA adalah laki-laki, sebagian besar berada pada usia remaja awal $(54,5 \%)$, dan sedang menempuh tingkat pendidikan SMA (52\%). Drug of Choice dan jenis NAPZA yang paling sering disalahgunakan adalah double $L$ masingmasing $97,35 \%$, dan $88,89 \%$ serta sebagian besar berjumlah 1 jenis $(91,53 \%)$. Kecamatan yang paling banyak pelajar yang menyalahgunakan NAPZA adalah kecamatan Sawahan, dan Tegalsari. Disimpulkan bahwa sebagian besar pelajar yang menyalahgunakan NAPZA berjenis kelamin laki-laki, berada pada usia remaja awal, jenis NAPZA yang digunakan sebagai Drug of Choice (DOC) dan yang paling banyak disalahgunakan adalah double L/Trihexyphenidyl sedangkan tempat tinggal pelajar yang paling banyak terlibat penyalahgunaan NAPZA di Sawahan, dan Tegalsari. Saran yang dapat dilakukan adalah skrining secara rutin pada pelajar, dan adanya pemeriksaan terhadap barang yang dibawa oleh siswa.
\end{abstract}

Kata kunci: penyalahguna NAPZA, jenis NAPZA, pelajar 


\section{PENDAHULUAN}

Narkotika, Psikotropika dan Zat Adiktif lainnya merupakan singkatan dari NAPZA yaitu zat kimia yang apabila masuk kedalam tubuh manusia baik dengan berbagai cara, baik dihisap, dihirup, diminum atau disuntikkan dapat berpengaruh pada pikiran, emosi, dan tindakan (Lumbantobing, 2007)

Hampir semua jenis NAPZA akan mengaktifkan satu sistem di otak yang mengatur rasa senang atau biasa disebut reward system dengan meningkatkan ketersediaan dopamin di otak, di mana dopamin merupakan suatu jenis neurotrasmitter yang bekerja mengontrol rasa senang. Jika penyalahguna terus menerus menggunakan NAPZA maka otak akan beradaptasi dengan keberadaan dopamine yang tinggi. Hal tersebut menyebabkan penggunaan NAPZA berusaha untuk menjaga agar fungsi dopamin dalam keadaan stabil atau berusaha menambah dosis NAPZA untuk mencapai dopamin yang tinggi, dan disertai dengan penggunaan yang dilakukan secara terus menerus atau kecanduan (Ikawati, 2016).

Kalangan pelajar yang berada pada kelompok usia remaja memiliki emosi yang masih labil sehingga sangat rentan untuk menyalahgunakan NAPZA. Hal tersebut bisa dikarenakan beberapa hal antara lain rasa ingin tahu yang sangat besar, ikutikutan teman, rasa solidaritas grup yang kuat sampai dengan faktor keluarga yang kurang perhatian. Anak remaja biasanya memiliki keinginan untuk mencari tahu sesuatu yang tidak diketahuinya (Simangunsong, 2015).

Usia remaja rentan terhadap penyalahgunaan NAPZA karena tingkat emosi dan mental masih sangat labil sehingga mudah terpengaruh ke dalam perilaku menyimpang. Remaja memiliki kecenderungan ingin tahu sehingga akan mencari informasi mengenai NAPZA, dan memiliki potensi memakai narkoba misalnya dimulai dengan sekedar cobacoba. Rasa ingin tahu terhadap narkotika dan psikotropika merupakan salah satu pendorong bagi seseorang untuk melakukan perbuatan yang menyimpang termasuk keingintahuan terhadap NAPZA (Sarwono, 2007).

Remaja merupakan masa transisi dari anak-anak menuju dewasa. Pada masa ini, seseorang tidak mau dianggap sebagai anakanak oleh lingkungan sekitar namun jika dilihat secara fisik, psikologi serta mental belum nampak tanda-tanda kedewasaan yang sesungguhnya (Razak dan Sayuti, 2006). Menurut Willis (2008), masa ini rentan terhadap adanya kenakalan remaja merupakan tindakan yang dilakukan remaja yang bertentangan dengan hukum, nilai maupun norma yang ada di masyarakat sehingga dapat merugikan dirinya sendiri maupun orang lain. Salah satu bentuk kenakalan remaja adalah penyalahgunaan NAPZA.

Tahap dalam penyalahgunaan NAPZA pada kalangan pelajar dapat diilustrasikan dengan skala besar yang dijelaskan oleh Willis (2008), bahwa pelajar yang sering bergaul di luar rumah tanpa mental yang kuat akan mudah untuk menyalahgunakan NAPZA karena teman-teman penyalahguna lain maupun pengedar yang sangat mahir untuk membujuknya. Pelajar yang telah mengalami ketergantungan terhadap NAPZA akan bergantung oleh zat yang dimiliki pengedar sehingga dapat pula pelajar tersebut juga membantu mengedarkan. Suatu sekolah yang terdapat satu pelajar yang telah ketergantungan NAPZA dapat pula menjadi tempat peredaran NAPZA di dalamnya. Siswa yang telah menyalahgunakan NAPZA bisa saja dikeluarkan dari sekolah supaya siswa lainnya tidak terkena pengaruh buruknya. Siswa tersebut kesulitan untuk mencari sekolah yang baru dan menjadi siswa putus sekolah. Hal tersebut menyebabkan semakin leluasanya bergaul dengan temanteman penyalahguna lainnya, dan berakibat ditangkap oleh polisi dan masuk penjara sehingga menjadi pengangguran karena sulit mencari kerja. Pengangguran rawan terjadi peredaran NAPZA yang akan mencari calon 
konsumen baru yang salah satunya adalah siswa sekolah.

Laporan perkembangan situasi NAPZA dunia tahun 2014 menyatakan angka estimasi pengguna tahun 2012 adalah antara 162 juta hingga 324 juta orang atau sekitar 3,5-7\%. Estimasi pengguna NAPZA tahun 2010 yang kisarannya 3,5-5,7\% (UNODC, 2014).

Prevalensi penyalahguna NAPZA di Indonesia setiap tahun selalu meningkat. Pada tahun 2011 prevalensinya sebesar 2,32\%, tahun 2013 sebesar 2,56\%, dan tahun 2015 sebesar 2,80\% (BNN RI, 2016b). Hasil penelitian yang dilakukan oleh BNN yang bekerjasama dengan Puslitkes Universitas Indonesia tahun 2011, penyalahgunaan NAPZA di Indonesia prevalensi paling tinggi $(2,2 \%)$ berada pada kelompok usia 10-59 tahun.

Kelompok usia 10-19 tahun merupakan kelompok usia pelajar. Prevalensi penyalahguna NAPZA di Kota Surabaya sebesar $0,012 \%$ sedangkan pelajar yang menyalahgunakan NAPZA di Kota Surabaya sebesar $0,0064 \%$. Berdasarkan penjangkauan yang telah dilakukan terhadap 359 penyalahguna NAPZA dari berbagai kelompok usia terdapat 189 pelajar yang terlibat penyalahgunaan NAPZA (BNN Kota Surabaya, 2015). Jumlah pelajar penyalahguna NAPZA di Surabaya selalu meningkat. Pada tahun 2013 terdapat 29 pelajar, tahun 2014 menjadi 37 pelajar, dan tahun 2015 meningkat menjadi 51 pelajar (Polrestabes Surabaya, 2015).

Penyalahgunaan NAPZA pada pelajar dapat disebabkan karena tekanan yang dirasakan remaja tersebut sehingga mereka yang tidak mampu menghadapinya melarikan diri, dan mencari ketenangan dengan menyalahgunakan NAPZA (Siskandar, 2010). Lingkungan juga memberikan efek yang besar pada diri seorang pelajar terutama lingkungan yang ada di luar rumah. Paling banyak remaja menghabiskan waktu di luar rumah. Selain itu, adanya suasana lingkungan yang berada di rumah tidak mendukung atau kurang sehat bagi pelajar karena orang tua yang terlalu sibuk sehingga anak merasa kurang diperhatikan. Hal ini menjadi salah satu penyebab anak lebih suka berhubungan dengan lingkungan luar rumah dibandingkan dengan keluarga di rumah (Hartadi, 2008).

Penyalahgunaan NAPZA pada remaja bukan suatu peristiwa yang timbul karena suatu pemicu melainkan akibat dari beberapa sebab yang merupakan faktor pendorong remaja tersebut menyalahgunakan NAPZA. Semakin besar akumulasi dari faktor pendorong tersebut meningkatkan risiko remaja dalam menyalahgunakan NAPZA (Setiawan, 2008)

Salah satu dampak dari NAPZA yaitu menyerang fungsi otak yang dapat mengakibatkan daya ingat menurun, sulit berkonsentrasi, menimbulkan perasaan khayal, dan kemampuan belajar merosot (BNN RI, 2012a). Keadaan seperti itulah yang menyebabkan pelajar bermalas-malasan sehingga prestasi belajar akan menurun. Pelajar merupakan generasi penerus bangsa. Penyalahgunaan NAPZA pada pelajar dapat merusak satu generasi yang akan berdampak pada hilangnya satu generasi kepemimpinan Tujuan penelitian ini adalah mempelajari karakteristik pelajar penyalahguna NAPZA, dan jenis NAPZA yang digunakan di Kota Surabaya.

\section{METODE PENELITIAN}

Penelitian ini adalah penelitian deskriptif. Waktu penelitian dilakukan pada 29 Agustus hingga 27 September 2016. Populasi dalam penelitian ini adalah pelajar penyalahguna NAPZA di Kota Surabaya tahun 2015. Sampel penelitian pada penelitian ini diambil dengan cara purposive sampling yaitu mengambil subjek didasarkan atas adanya tujuan tertentu (Arikunto, 2010). Sampel pada penelitian ini adalah pelajar yang dapat dijangkau oleh $\mathrm{BNN}$ Kota Surabaya sebesar 189 orang. Teknik pengumpulan data yang digunakan adalah data sekunder yang diperoleh dari dokumen yang tersedia pada bagian rehabilitasi BNN Kota Surabaya. 
Dokumen yang digunakan adalah data penyalahguna NAPZA di Kota Surabaya tahun 2015 namun dikhususkan pada pelajar. Dokumen yang tersedia berisi informasi umum seperti nama, tanggal lahir, jenis kelamin, alamat, pendidikan terakhir, profesi, jenis NAPZA yang disalahgunakan, Drug of Choice atau jenis zat utama yang disalahgunakan, jenis rehabilitasi yang dijalani, dan tempat rehabilitasi. Jenis rehabilitasi yang dimaksud adalah rawat jalan atau rawat inap. Rawat jalan yang berupa kegiatan konseling sedangkan rawat inap terdapat berbagai kegiatan yang dilakukan untuk menghindari relapse, dan meningkatkan kualitas hidup penyalahguna.

Analisis data yang dilakukan secara deskriptif adalah dengan cara menganalisis data sekunder yang disajikan dalam bentuk tabel dan narasi. Langkah-langkah dalam melakukan analisis data yaitu peneliti memilah hal-hal pokok dan hanya fokus pada hal penting serta data yang dibutuhkan kemudian data yang telah diperoleh tersebut disajikan dalam bentuk tabel maupun narasi, dari hasil penyajian data dapat ditarik kesimpulan dari penelitian tersebut.

\section{HASIL}

\section{Karakteristik Responden}

Karakteristik responden dalam penelitian ini meliputi jenis kelamin, usia, dan tingkat pendidikan. Tabel 1 menunjukkan bahwa jenis kelamin responden sebagian besar laki-laki (80,95\%), sebagian besar responden berada pada usia remaja awal $(54,45 \%)$. Usia remaja dibagi menjadi tiga kategori antara lain remaja awal yang berusia antara 1215 tahun, remaja pertengahan berada pada rentang usia 16-18 tahun, dan remaja akhir berada pada rentang usia 19-21 tahun. Tabel 1 menunjukkan bahwa pelajar SMP dan SMA tidak memiliki perbedaan jumlah yang besar dalam menyalahgunakan

NAPZA namun pelajar SMA merupakan responden yang paling banyak menyalahgunakan NAPZA (52\%).
Tabel 1. Distribusi Responden Berdasarkan Karaktersitik

\begin{tabular}{lcc}
\hline \multicolumn{1}{c}{ Karakteristik } & $\begin{array}{c}\text { Frekuensi } \\
(\mathbf{n}=\mathbf{1 8 9})\end{array}$ & $\mathbf{\%}$ \\
\hline Jenis Kelamin & & \\
- Laki-laki & 153 & 80,95 \\
- Perempuan & 36 & 19,05 \\
\hline Usia & & \\
- Remaja Awal & 103 & 54,5 \\
- Remaja & 85 & 44,5 \\
- Pertengahan & & \\
- Remaja Akhir & 1 & 1 \\
\hline Tingkat Pendidikan & & \\
- SMP & & \\
- SMA & 91 & 48 \\
& 98 & 52 \\
\hline
\end{tabular}

\section{Distribusi Pelajar Penyalahguna NAPZA}

Distribusi pelajar yang menyalahgunakan NAPZA dapat dijabarkan antara lain jenis NAPZA sebagai Drug of Choice, jenis NAPZA yang disalahgunakan, jumlah penyalahgunaan NAPZA, dan kecamatan tempat tinggal pelajar penyalahguna NAPZA.

Tabel 2 menunjukkan bahwa hampir seluruh pelajar menggunakan double $L$ sebagai Drug of Choice sebesar 97,35\%. Penyalahgunaan sabu sebagai urutan kedua terbanyak memiliki jumlah yang cukup jauh dengan urutan pertama yaitu hanya $2,12 \%$, sebagian besar jumlah NAPZA yang disalahgunakan hanya satu sebesar $91,53 \%$.

Tabel 2 menunjukkan berbagai jenis NAPZA yang disalahgunakan pelajar. Frekuensi atau jumlah semakin bertambah dari jenis NAPZA sebagai Drug of Choice (DOC) karena pada 1 pelajar dapat menggunakan berbagai jenis NAPZA. Jenis NAPZA yang paling sering digunakan pelajar adalah double L sebesar $88,89 \%$. Double L merupakan sebutan dari trihexyphenidyl yang termasuk dalam psikotropika golongan IV. Dalam kesehatan, trihexyphenidyl digunakan untuk mengatasi gangguan gerakan yang tidak normal (tremor). 
Tabel 2. Penyalahgunaan NAPZA Pada Pelajar

\begin{tabular}{lrr}
\hline \multicolumn{1}{c}{$\begin{array}{c}\text { Penyalahgunaan } \\
\text { NAPZA }\end{array}$} & Frekuensi & \multicolumn{1}{c}{$\%$} \\
\hline $\begin{array}{l}\text { Jenis NAPZA } \\
\text { sebagai DOC }\end{array}$ & & \\
$\quad$ Double $L$ & & \\
Sabu & 184 & 97,35 \\
Ganja & 4 & 2,12 \\
Total & 1 & 0,53 \\
\hline Jenis NAPZA & 189 & 100,00 \\
$\quad$ Double L & 184 & 88,89 \\
Sabu & 13 & 6,28 \\
Ganja & 5 & 2,41 \\
Alkohol & 4 & 1,93 \\
Arkin & 1 & 0,09 \\
\hline Total & 207 & 100,00 \\
\hline Jumlah NAPZA & & \\
1 & 173 & 91,53 \\
2 & 14 & 7,41 \\
3 & 2 & 1,06 \\
\hline Total & 189 & 100,00 \\
\hline
\end{tabular}

Tempat tinggal pelajar penyalahguna NAPZA tersebar pada 21 kecamatan. Kawasan merah merupakan kecamatan tempat tinggal pelajar yang paling banyak menjadi penyalahguna NAPZA di mana pada satu kawasan tersebut terdapat lebih dari 20 pelajar yang menjadi penyalahguna NAPZA. Tabel 3 menunjukkanbahwa tempat tinggal pelajar berdasarkan kecamatan yang berada pada kawasan merah adalah Sawahan dengan 31\% dan Tegalsari 17\% sedangkan kecamatan yang paling kecil diantaranya Mulyorejo, Semampir, Pabean Cantian, Wiyung, Lakarsantri, dan Benowo masingmasing sebesar $1 \%$.

\section{PEMBAHASAN}

Pelajar berada pada usia remaja yang rentan terhadap penyalahgunaan NAPZA. Pada usia remaja, dorongan keingintahuan akan sesuatu hal sangat besar, merasa sudah dewasa sehingga ingin mengambil risiko dengan mencoba hal-hal yang belum diketahui sebelumnya. Selain itu, biasanya para remaja sering berkumpul dengan teman sebayanya sehingga setiap kegiatan yang
Tabel 3. Tempat Tinggal Pelajar Penyalahguna NAPZA

\begin{tabular}{lcc}
\hline Kecamatan & $\begin{array}{c}\text { Frekuensi } \\
(\mathbf{n}=\mathbf{1 8 9})\end{array}$ & $\mathbf{\%}$ \\
\hline Dukuh Pakis & 11 & 6 \\
Krembangan & 17 & 9 \\
Gubeng & 7 & 4 \\
Bubutan & 5 & 2,5 \\
Tambaksari & 19 & 10 \\
Sukolilo & 7 & 4 \\
Sawahan & 58 & 31 \\
Wonokromo & 4 & 2 \\
Tegalsari & 32 & 17 \\
Kenjeran & 3 & 1,5 \\
Genteng & 4 & 2 \\
Mulyorejo & 1 & 0,5 \\
Semampir & 1 & 0,5 \\
Pabean Cantian & 1 & 0,5 \\
Asemrowo & 2 & 1 \\
Wiyung & 1 & 0,5 \\
Sukomanunggal & 10 & 5 \\
Simokerto & 2 & 1 \\
Lakarsantri & 1 & 0,5 \\
Benowo & 1 & 0,5 \\
Tandes & 2 & 1 \\
\hline
\end{tabular}

dilakukan oleh teman-teman lainnya akan dicontoh (BNN RI, 2012b).

Hal tersebut menyebabkan pelajar menjadi sasaran bagi para pengedar NAPZA. Beberapa alasan remaja dalam menyalahgunakan NAPZA antara lain merasa tertekan bahkan depresi sehingga membutuhkan NAPZA untuk menghilangkan perasaan tersebut, pergaulan dengan teman yang juga menyalahgunakan NAPZA, perkembangan jiwa remaja yang menuntut pemisahan dari aturan orang tua dan mencari identitas diri dengan mengikuti pola hidup kelompok sebayanya, penggunaan NAPZA dianggap sebagai pola hidup baru, keingintahuan yang besar dalam mengeksplorasi dunia sekitarnya, dan mencoba hal baru untuk mencari pengalaman hidup baru, penyalahgunaan NAPZA dapat dipandang sebagai suatu penyaluran dorongan untuk melakukan perbuatan yang memiliki risiko besar karena remaja berjiwa 


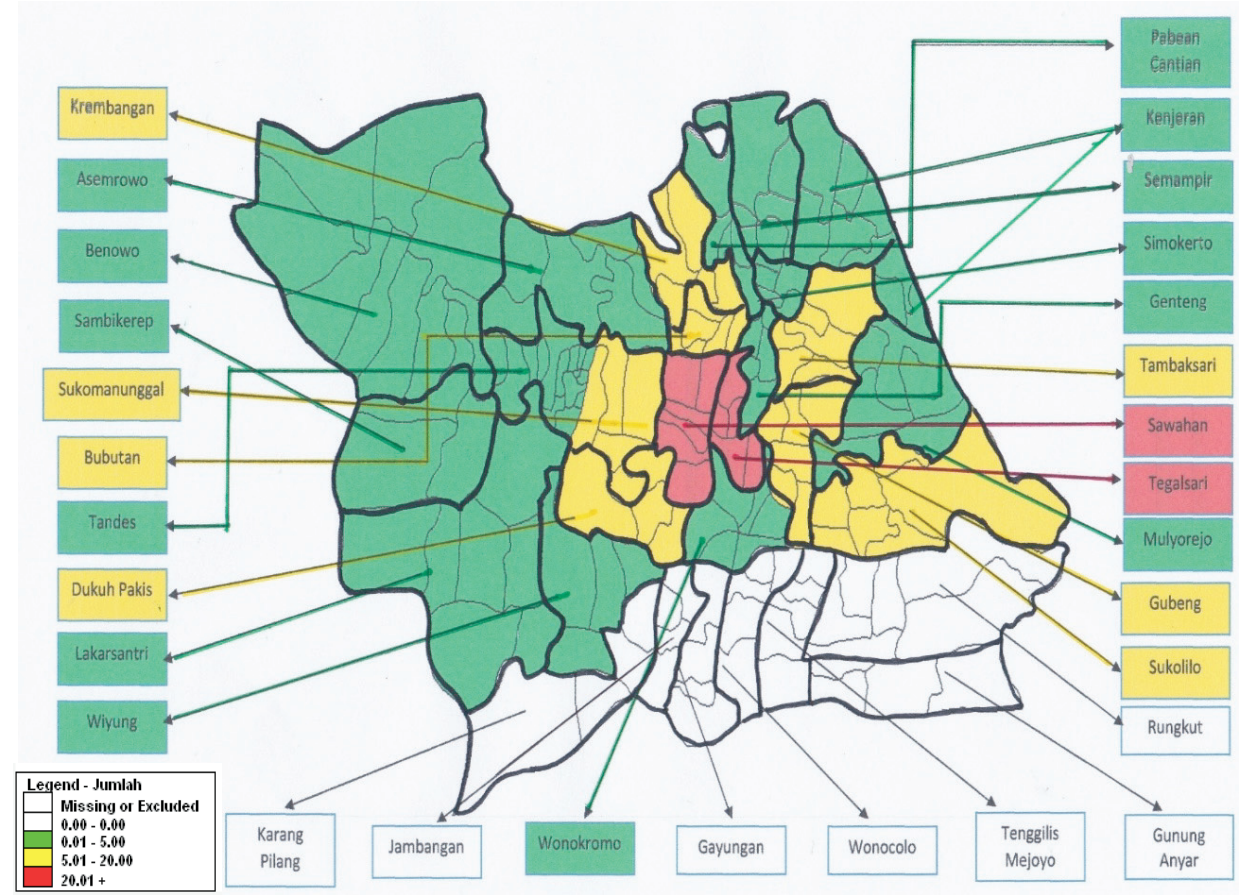

Gambar 1. Tempat Tinggal Pelajar Penyalahguna NAPZA.

petualang yang tinggi, penyalahgunaan NAPZA menurut mereka merupakan simbol kedewasaan (Siskandar, 2010).

NAPZA merupakan zat yang sangat menimbulkan adiksi. Menurut BNN RI (2007), adiksi merupakan suatu kondisi ketergantungan fisik maupun psikologis terhadap suatu hal yang dapat menimbulkan perubahan perilaku pada orang yang mengalaminya. Adiksi dapat membuat seseorang untuk menggunakan secara terus menerus dengan peningkatan dosis serta terdapat ketidakmampuan dalam menghentikan konsumsi NAPZA. Menurut Sumiati (2009), ketergantungan dibagi menjadi dua yaitu ketergantungan fisik yaitu suatu keadaan jika penyalahguna mengurangi dosis yang biasa digunakan akan mengalami gejala putus zat sedangkan ketergantungan secara psikologis yaitu suatu keadaan bila berhenti menggunakan NAPZA penyalahguna akan mengalami kerinduan yang sangat kuat untuk menggunakannya walaupun ia tidak mengalami gejala fisik.

Pada fase ketergantungan, tubuh memerlukan sejumlah dosis zat yang dipakai agar ia dapat berfungsi normal. Selama pasokan NAPZA cukup, ia tampak sehat, meskipun sebenarnya sakit. Akan tetapi, jika pemakaiannya dikurangi atau dihentikan, timbul gejala sakit. Hal ini disebut gejala putus zat (sakaw). Gejalanya bergantung pada jenis zat yang digunakan. Orang pun mencoba mencampur berbagai jenis NAPZA agar dapat merasakan pengaruh zat yang diinginkan, dengan risiko meningkatnya kerusakan organ-organ tubuh. Gejala lain ketergantungan adalah toleransi, suatu keadaan di mana jumlah NAPZA yang dikonsumsi tidak lagi cukup untuk menghasilkan pengaruh yang sama seperti yang dialami sebelumnya. Oleh karena itu, jumlah yang diperlukan meningkat. Jika jumlah NAPZA yang dipakai berlebihan (overdosis), dapat terjadi kematian (Harlina dan Juwana, 2008).

Tingginya tingkat adiksi (ketergantungan) dari suatu NAPZA akan memengaruhi kualitas hidup penyalahgunanya. Jika seseorang ketagihan, maka NAPZA akan menjadi bagian dari hidupnya. Tubuhnya tidak akan mampu lagi menjalankan fungsi-fungsinya tanpa mengonsumsi dalam dosis yang biasanya. 
Dia akan merasakan sakit yang luar biasa jika tidak bisa memperolehnya (Kusuma, 2014).

Penyalahgunaan NAPZA menurut Hawari (2009), memiliki karakteristik khusus yang merupakan suatu hubungan sebab akibat yang saling terkait. Proses tersebut terdiri atas faktor predisposisi meliputi kepribadian, kehidupan beragama, gangguan kejiwaan sedangkan faktor kontribusi meliputi kondisi keluarga, sekolah, dan lingkungan serta faktor pencetus.

Faktor predisposisi merupakan faktor bawaan sejak lahir antara lain kepribadian. Kepribadian merupakan segala kebiasaan dalam dirinya yang digunakan dalam penyesuaian diri dengan lingkungan sekitar, kebiasaan tersebut merupakan corak yang khas dari individu tersebut (Willis, 2008).

Menurut Nurdin (2007), penyalahguna NAPZA menderita disregulasi afektif berupa depresi yang dapat diringankan dengan zat psikoaktif sehingga dapat dikatakan bahwa penyalahguna merupakan seseorang yang menderita gangguan pengendalian impuls yang didorong untuk mencari kenikmatan dan mendominasi berbagai impuls lainnya.

Faktor kontribusi adalah faktor yang ada di luar diri seseorang dan berfungsi sebagai pendorong sebelum melakukan sesuatu. Faktor-faktor yang berasal dari keluarga yang dapat menyebabkan remaja terjerumus dalam NAPZA antara lain keluarga yang kurang harmonis, tidak komunikastif terhadap anak, terlalu otoriter terhadap anak, selalu menuntut prestasi terbaik pada anak dengan cara memaksa, dan kurang memberikan perhatian pad anak karena sibuk dengan aktivitas sendiri (Rozak dan Sayuti, 2006)

$$
\text { Menurut Hawari (2009), }
$$
penyalahgunaan NAPZA selain karena pengaruh teman sebaya juga karena ketidaktahuannya bahwa zat tersebut haram baik dari sisi agama maupun hukum. NAPZA terutama gangguan susunan saraf pusat yang mengakibatkan gangguan mental dan perilaku yang bisa memengaruhi akademik.
Willis (2008), menjelaskan bahwa pendidikan moral dan agama seharusnya diberikan sesuai dengan usia.

Penelitian yang dilakukan oleh Setiawan (2008), menunjukkan hasil bahwa penyalahgunaan NAPZA merupakan kombinasi dari tiga faktor antara lain faktor predisposisi yang mencakup kepribadian, dan keagamaan, faktor kontribusi meliputi interaksi dengan lingkungan atau pergaulan, dan faktor pencetus yaitu ketersediaan, dorongan dari dalam diri sendiri, dan gaya hidup. Ketiga faktor tersebut yang dominan adalah faktor kontribusi, dan pencetus. Menurut Nurdin (2007), beberapa faktor pencetus seseorang menyalahgunakan NAPZA antara lain mengatasi perasaaan tidak bahagia (anhedonia), pelampiasan nafsu (hedonisme banal), mencapai kenikmatan sempurna (ultimate aesthetica), meringankan perasaan kalah terhadap lingkungan (doping), suatu pemberontakan (mind in rebellion), identitas yang salah (mal identification), pengalaman spiritual (supernatural) serta untuk mengatasi rasa takut dan bersalah (disinhibisi)

Dampak yang ditimbulkan dari adanya ketergantungan NAPZA tidak hanya bagi dirinya sendiri namun juga bisa berpengaruh pada lingkungan. Menurut BNN RI (2010), dampak dari penyalahgunaan NAPZA dikenal dengan istilah 4L yaitu liver, lover, lifestyle, dan legal. Liver merupakan dampak langsung yang menyerang penyalahguna NAPZA dan dapat merusak organ vital seperti otak, hati, paru, dan ginjal. Lover berarti adanya hubungan yang rusak dengan orang yang dicintai misalnya keluarga. Penyalahguna biasanya selalu dalam pengaruh NAPZA sehingga selalu menomorsatukan zat tersebut sehingga membuat dirinya lupa akan kewajiban dan tidak lagi memperdulikan orang lain. Lifestyle yang rusak ditandai dengan kondisi dirinya yang merasa malas untuk melakukan sesuatu, sering bolos sehingga prestasi sekolah menurun yang menyebabkan putus sekolah, dan cita-cita berantakan. Penelitian 
oleh Sembiring (2015), menyatakan bahwa remaja yang pernah menjadi penyalahguna NAPZA mengalami terganggunya fungsi otak seperti kemampuan daya ingat Selainitu remaja menjadi pribadi yang tidak disiplin dan terkadang mengganggu ketenangan belajar- mengajar. Hal ini juga diperkuat oleh Ardiantina (2016), yang menyebutkan bahwa pelajar yang menyalahgunakan NAPZA memiliki penurunan kemampuan daya ingat jangka pendek yang rendah sehingga menurunkan prestasi akademik.

Pelajar umumnya masih mendapat uang saku dari orang tua namun karena kebutuhan terhadap NAPZA sangat besar biayanya penyalahguna tersebut bisa saja mencuri uang atau barang, menjual NAPZA kepada teman-temannya di mana hal tersebut termasuk dalam aspek legal/hukum. Pelajar merupakan generasi penerus bangsa yang sangat dibutuhkan untuk pembangunan jangka panjang dalam mendapatkan Sumber Daya Manusia yang berkualitas.

Pada tahun 2016, pelajar yang menyalahgunakan NAPZA sebagian besar adalah laki-laki di Kota Surabaya. Hal tersebut serupa dengan hasil Survei Kesehatan Reproduksi Remaja Indonesia di Indonesia tahun 2007 bahwa lakilaki memiliki peluang 20 kali dalam menyalahgunakan narkoba, dan 10 kali dalam menyalahgunakan alkohol.

Hal senada diungkapkan pula oleh Afandi dkk (2009), bahwa remaja laki-laki lebih ambisius dan memiliki tingkat agresi yang lebih tinggi dibandingkan dengan remaja perempuan. Diperkuat oleh pendapat yang dikemukakan oleh Kartono (2010), bahwa salah satu faktor yang memengaruhi kenakalan pada remaja adalah jenis kelamin. Tingginya kasus penyalahgunaan NAPZA pada laki-laki disebabkan oleh beberapa hal antara lain kepribadian laki-laki yang cenderung ingin terlihat berani dan jantan, pemberontakan dalam keluarga juga banyak dilakukan oleh kaum laki-laki dan laki-laki cenderung lebih senang bergaul secara berkelompok sehingga mereka akan melakukan berbagai hal agar dapat diterima dalam kelompok tersebut sehingga jika terdapat salah satu anggota kelompok yang menyalahgunakan narkoba maka anggota kelompok yang lain cenderung mengikuti perilaku menyimpang tersebut (Shekarchizadeh dkk, 2012).

Usia remaja awal paling banyak yang menyalahgunakan NAPZA di Kota Surabaya tahun 2015. Menurut Deswita (2006), remaja awal berusia $12-15$ tahun. Hal ini serupa dengan penelitian yang dilakukan oleh Jaji (2009), bahwa remaja yang paling banyak menyalahgunakan NAPZA berada pada usia 13-15 tahun. Remaja awal merupakan usia peralihan dari masa anak-anak menuju kedewasaan dan cenderung ingin merasakan hal-hal yang belum mereka rasakan sebelumnya. Rasa penasaran yang tinggi, dan didukung oleh teman sebayanya yang juga menyalahgunakan NAPZA menyebabkan pelajar tersebut terjerumus dalam penyalahgunaan NAPZA.

Sebagian besar penyalahguna NAPZA yang disebabkan oleh kondisi sosial psikologi yang membutuhkan pengakuan identitas terhadap dirinya, dan dalam mengontrol emosi masih belum begitu baik. Masa remaja awal (14-16 tahun) dan remaja tengah (17-18 tahun) umumnya belum menemukan jati dirinya sedangkan masa remaja akhir $(>$ 18 tahun) mereka merasa sudah cukup dewasa dan mampu untuk mandiri namun disisi lain belum mampu mempertanggungjawabkan tindakannya (Siregar, 2004)

Penelitian ini didapatkan bahwa antara pelajar SMP dan SMA tidak ada perbedaan terlalu jauh dalam hal jumlah penyalahguna namun paling banyak sedang menempuh pendidikan SMA. Hal ini bertentangan dengan penelitian yang dilakukan oleh Jaji (2009). Menurut Jaji, paling besar remaja SMP yang menyalahgunakan NAPZA. Hal ini dapat terjadi karena tempat penelitian dan tahun penelitian berbeda sehingga karakteristik pelajar penyalahguna NAPZA juga berbeda. 
Menurut survei yang dilakukan oleh BNN RI pada tahun 2015 50\% penyalahguna NAPZA adalah pelajar/mahasiswa (BNN RI, 2016a). Selain itu, survei yang dilakukan oleh BNN tahun 2011 menyatakan bahwa $4,3 \%$ pelajar/mahasiswa Indonesia pernah menyalahgunakan NAPZA (BNN RI, 2011). Remaja Indonesia saat ini tidak hanya berstatus sebagai penyalahguna tetapi juga pengedar. Survei yang dilakukan oleh BNN tahun 2011 menunjukkan dari 100 pelajar/ mahasiswa, terdapat empat orang pernah menyalahgunakan NAPZA, tiga orang menyalahgunakan dalam satu tahun terakhir dan dua sampai tiga orang dalam satu bulan terakhi (BNN RI, 2012b).

Drug of Choice adalah satu jenis zat yang paling sering dikonsumsi oleh penyalahguna NAPZA dapat dikarenakan tubuhnya merasa nyaman dengan penggunaan zat tersebut. Pada penelitian ini, Drug of Choice pelajar penyalahguna NAPZA adalah double L. Double L adalah sejenis pil yang termasuk dalam psikotropika golongan IV. Hal ini bertentangan dengan penelitian yang dilakukan oleh Shekarchizadeh (2012) yang menyatakan Drug of Choice di Tehran, Iran adalah opium. Hal ini tentu bisa saja dipengaruhi oleh usia, usia pada penelitian Shekarchizadeh dari berbagai kelompok usia tidak hanya pelajar.

Jenis NAPZA yang paling sering disalahgunakan oleh pelajar adalah double $L$. Hal ini serupa dengan penelitian yang dilakukan oleh Ayudya dan Harmanto (2015), menyebutkan bahwa terdapat penyalahgunaan double $L$ pada penyalahguna di SMA. Pelajar menggunakan NAPZA biasanya sudah memakai sejak SMP dan memperlancar penggunaannya di SMA ini. Kelompok pelajar lebih banyak menyalahgunakan jenis depresan seperti berbagai jenis benzodiazepin untuk mengurangi stres (BNN RI, 2015a). Trihexyphenidyl atau yang lebih dikenal dengan pil double $\mathrm{L}$ adalah obat untuk mengatasi gangguan gerakan tidak normal. Trihexyphenidyl termasuk dalam sedatif hipnotik. Sedatif adalah substansi yang dapat memberikan efek menenangkan, dan hipnotik adalah substansi dapat memberikan efek kantuk. Penyalahgunaan double $L$ merupakan pintu masuk bagi pelajar untuk menggunakan NAPZA dengan tingkat adiksi lebih kuat lagi. Penggunaan double L pada pelajar cukup meluas dikarenakan harga yang relatif murah.

Jumlah NAPZA yang dikonsumsi pelajar sebagian besar hanya satu jenis. Hal ini tidak sesuai dengan penelitian yang dilakukan oleh Kholik dkk (2014), bahwa sebagian besar menyalahgunakan lebih dari 2 jenis. Hasil yang berbeda dapat dipengaruhi antara lain perbedaan tempat penelitian, dan usia responden. Pada penelitian yang dilakukan oleh Kholik, usia responden paling banyak 21-30 tahun. Selain itu harga double $L$ yang relatif lebih murah dari jenis lainnya juga merupakan salah satu faktor penyebab.

Gambar 1 menunjukkan kecamatan yang paling tinggi pelajar yang menyalahgunakan NAPZA berdasarkan tempat tinggal adalah Sawahan, dan Tegalsari yang ditunjukkan dengan warna merah. Warna merah memiliki makna bahwa di kawasan tempat tinggal pelajar tersebut, pelajar yang menyalahgunakan NAPZA lebih dari 20 orang. Lingkungan merupakan salah satu risiko pelajar dalam menyalahgunakan NAPZA. Lingkungan pertemanan sekolah maupun lingkungan tempat tinggal merupakan risiko pelajar dalam menyalahgunakan NAPZA.

Lingkungan tempat tinggal di mana terdapat penyalahgunaan NAPZA memberikan kesempatan untuk para pelajar ikut mencoba pelajar ikut mencoba zat tersebut. Penyalahgunaan NAPZA pada lingkungan yang masyarakatnya mayoritas menyalahgunakan NAPZA dan membentuk pola pikir bahwa penyalahgunaan tersebut merupakan suatu kewajaran dan hal yang biasa untuk dilakukan.

Keadaan di sekitar tempat tinggal baik dari aspek fisik, sosial maupun lingkungan sangat penting terhadap penyelahgunaan 
NAPZA. Menurut hasil penelitian Hawari (2009), faktor lingkungan substance availibility berperan sebagai faktor pencetus perilaku penyalahguna NAPZA dengan predisposisi gangguan kepribadian. Lingkungan fisik adalah kondisi sekitar tempat tinggal yang dinilai ketersediaan fasilitas sarana dan prasarana.

Hasil penelitian dari Setiawan (2008), menunjukkan bahwa remaja yang hidup di lingkungan tersebut akan mudah terpengaruh penyimpangan sosial karena hal tersebut merupakan suatu hal yang biasa misalnya remaja yang suka mengonsumsi alkohol atau NAPZA yang melakukan perilaku tersebut di tempat umum tanpa merasa risih. Pola pertemanan dan lingkungan pergaulan memiliki risiko terkait kenakalan remaja termasuk penyalahgunaan NAPZA. Teman kelompok sebaya memiliki pengaruh yang dapat mendorong penyalahgunaan NAPZA pada diri seseorang. Pengaruh teman kelompok dapat menciptakan keterikatan dan kebersamaan sehingga sulit untuk melepaskan diri. Pengaruh teman kelompok tersebut tidak hanya pada saat perkenalan pertama saja namun bisa juga menyebabkan kekambuhan.

\section{SIMPULAN}

Kesimpulan yang didapat dari penelitian ini adalah sebagian besar pelajar yang menyalahgunakan NAPZA berjenis kelamin laki-laki berada pada usia remaja awal, dan sedang menempuh pendidikan tingkat SMA. Jenis NAPZA yang digunakan sebagai Drug of Choice (DOC) dan yang paling banyak disalahgunakan adalah double L/Trihexyphenidyl sedangkan tempat tinggal pelajar yang paling banyak terlibat penyalahgunaan NAPZA di Sawahan, dan Tegalsari.

Saran yang dapat diajukan bagi BNN Kota Surabaya adalah adanya skrining urin maupun melalui kuesioner ketergantungan yang dilakukan pada sekolah yang berada di Sawahan dan Tegalsari, diadakan kegiatan Training of Trainer (TOT) yang pesertanya adalah perwakilan guru SMP dari setiap sekolah yang membahas tentang jenis NAPZA yang sering disalahgunakan (double L) serta efek yang ditimbulkan. Bagi sekolah adalah diadakannya inspeksi yang dilakukan mendadak untuk mengetahui NAPZA yang dibawa oleh siswa, dan adanya kegiatan penggiat antinarkoba yang sebagian besar pesertanya adalah siswa laki-laki.

\section{DAFTAR PUSTAKA}

Afandi, D., Chandra, F., Novitasari, D., Riyanto, I., Kurniawan, L. 2009. Tingkat Penyalahgunaan Obat dan Faktor Risiko di Kalangan Siswa Sekolah Menengah Umum. Majalah Kedokteran Indonesia 59 (6): pp. 266-271.

Ardiantina, D. 2016. Studi Kasus Kehidupan Remaja Mantan Pecandu Narkoba. Jurnal Bimbingan dan Konseling Universitas Negeri Yogyakarta 1 (5): pp. 1-12.

Arikunto, S. 2010. Prosedur Penelitian: Suatu Pendekatan Praktik. Jakarta: Rineka Cipta.

Ayudya, KM., dan Harmanto. 2015. Strategi

Pembinaan Moral Bagi Siswa Pengguna Narkoba di SMK ABC Surabaya. Kajian Moral dan Kewarganegaraan 3 (3): pp. 1308-1323

Badan Narkotika Nasional Republik Indonesia. 2007. Mengenal Penyalahgunaan Narkoba, Buku 2 A untuk Remaja/Anak Muda. Jakarta: Deputi Bidang Pencegahan Direktorat Diserminasi Informasi.

Badan Narkotika Nasional Republik Indonesia. 2010. Pelajar dan Bahaya Narkotika. Jakarta: Deputi Bidang Pencegahan Direktorat Diserminasi Informasi.

Badan Narkotika Nasional Republik Indonesia. 2011. Survei Nasional Perkembangan Penyalahgunaan dan Peredaran Gelap Narkoba Pada Kelompok Pelajar dan Mahasiswa di 16 Provinsi di Indonesia Tahun 2011. Tersedia di 
http://www.bnn.go.id/portal/_uploads/ post/2012/05/29/2012052914503210261.pdf [3 September 2016]

Badan Narkotika Nasional Republik Indonesia. 2012a. Buku Pedoman Penggolongan Narkotika Berdasarkan Undang-Undang Nomor 35 Tahun 2009 Tentang Narkotika. Jakarta: Badan Narkotika Nasional Republik Indonesia.

Badan Narkotika Nasional Republik Indonesia. 2012b. Ringkasan Eksekutif, Survei Nasional Perkembangan Penyalahgunaan dan Peredaran Gelap Narkoba pada Kelompok Pelajar/ Mahasiswa di Indonesia Tahun 2011. Jakarta: Badan Narkotika Nasional Republik Indonesia.

Badan Narkotika Nasional Republik Indonesia. 2016a. Survei Prevalensi Penyalahgunaan Narkoba pada Kelompok Rumah Tangga di 20 Provinsi Tahun 2015. Jakarta: Pusat Penelitian Data dan Informasi.

Badan Narkotika Nasional Republik Indonesia. 2016b. Data Tindak Pidana Narkoba Tahun 2011-015. Tersedia di http://www.bnn.go.id/[ 1 September 2016]

BNN Kota Surabaya. 2015. Data Penjangkauan Bidang Rehabilitasi Tahun 2015

Deswita. 2006. Psikologi Perkembangan. Bandung: Remaja Rosdakarya.

Harlina, L., dan Joewana, S. 2008. Menangkal Narkoba dan Kekerasan. Jakarta: Balai Pustaka.

Hartadi, C. 2008. Penyalahgunaan Obat di Kalangan Remaja dan Pelajar. Tersedia di http://Kiis-Jakarta.Org/ Files/303009napza [1 September 2016]

Hawari, D. 2009. Penyalahgunaan dan Ketergantungan NAPZA. Jakarta: Balai Penerbitan FKUI.

Ikawati, Z. 2016. Mengapa Orang Bisa Kecanduan NAPZA. Tribun Jogja pp.13

Tersedia di http://farmasi.ugm.ac.id/files/ piotribun/2016-5-22-527805Mengapaorang-bisa-kecanduan-NAPZA.pdf [10 September 2016]
Jaji. 2009. Hubungan Faktor Sosial dan Spiritual dengan Risiko Penyalahgunaan NAPZA pada Remaja SMP dan SMA di Kota Palembang. Jurnal Pembangunan Manusia, 4 (2) pp. 150-160.

Kartono, K. 2010. Patologi Sosial II: Kenakalan Remaja. Jakarta: Rajagrafindo Persada.

Kholik, S., Mariana, ER., dan Zainab. 2014. Faktor-Faktor yang Memengaruhi Penyalahgunaan Narkoba Pada Klien Rehabilitasi Narkoba dDi Poli Napza Rsj Sambang Lihum. Jurnal Skala Kesehatan 5 (1): pp.1-8. Tersedia di http://www. ejurnalskalakesehatan-poltekkesbjm. com/index.php/JSK/article/view/13/26 [31 Agustus 2016]

Lumbantobing. 2007. Serba-Serbi Narkotika. Jakarta: Universitas Indonesia.

Masngudin, H.M.S. 2007. Kenakalan Remaja Sebagai Perilaku Menyimpang Hubungannya dengan Keberfungsian Sosial. Journal Psikologi UKS pp. 3-5.

Nurdin, A.E. 2007. Madat, Sejarah, Dampak Klinis Dan Penanggulangannya. Semarang: Mutiara Wacana.

Razak, A., dan Sayuti, W. 2006. Remaja dan Bahaya Narkoba. Jakarta: Prenada Media.

Riyadi, A. 2015. Risiko Penyalahgunaan NAPZA Pada Remaja Ditinjau dari Jenis Kelamin, Status Tinggal, dan Status Orang Tua. Skripsi. Universitas Muhammadiyah Surakarta.

Sarwono, S.W. 2007. Psikologi Remaja. Jakarta: Rajawali Pers.

Sembiring, N.F. 2015. Faktor-faktor Penyalahgunaan Narkoba pada Remaja di Lingkungan XIV Kelurahan Glugur Kota 10 Jurnal Bimbingan dan Konseling 1 (5): pp. 1-12.

Setiawan, H.S. 2008. Faktor-faktor Penyalahgunaan Narkoba Pada Siswa Sekolah Lanjutan Tingkat Atas. Tesis. Universitas Indonesia. Tersedia di http:// lib.ui.ac.id/file?file=digital/120514-T\%20 25580-Faktor\%20-\%20Faktor-Literatur. pdf [30 Agustus 2016] 
Shekarchizadeh, H., Hamed E, Mohammad R.K, Jorma I.V. 2012. Patterns of pretreatment drug abuse, drug treatment history and characteristics of addicts in methadone maintenance treatment in Iran. Harm Reduction Journal 9 (18): pp. 1-7.

Simangunsong, J. 2015. Penyalahgunaan Narkoba di Kalangan Remaja. Skripsi: Universitas Maritim Raja Ali Haji Tanjung Pinang.

Siregar, M. 2004. Faktor-faktor yang memengaruhi Penyalahgunaan Narkoba pada Remaja. Jurnal Pemberdayaan Komunitas 3(2): pp. 100-105.
Siskandar. 2010. Pengembangan Model Penanggulangan Narkoba Bagi Mahasiswa, Pelajar Dan Pemuda. Journal UNY 36 (1): pp. 41-55. Tersedia di journal.uny.ac.id/index.php/informasi/ article/view/5663/4889 [3 September 2016]

Sumiati. 2009. Kesehatan Jiwa Remaja dan Konseling. Jakarta: Trans Info Media.

United Nations Office on Drug and Crime (UNODC). 2012. World Drug Report. United Nations Publication.

Willis, S. 2008. Remaja dan Masalahnya. Bandung: Alfabeta. 